\title{
Pargamicin A, a Novel Cyclic Peptide Antibiotic from Amycolatopsis sp.
}

\author{
Masayuki Igarashi, Ryuichi Sawa, Naoko Kinoshita, Hideki Hashizume, \\ Naoko Nakagawa, Yoshiko Homma, Yoshio Nishimura, Yuzuru Akamatsu
}

Received: February 29, 2008 / Accepted: June 13, 2008

(C) Japan Antibiotics Research Association

\begin{abstract}
A novel cyclic peptide antibiotic, pargamicin A was isolated from the culture broth of an actinomycete strain. The producing organism, designated ML1-hF4, was identified as a member of the genus Amycolatopsis. Pargamicin A was identified as a novel cyclic hexapeptide antibiotic containing piperazic acid by various spectroscopic analyses. Pargamicin A showed potent antibacterial activity against Staphylococcus aureus strains including MRSA and Enterococcus faecalis/faecium strains including VRE.
\end{abstract}

Keywords pargamicin A, cyclic peptide, Amycolatopsis sp., MRSA, VRE

\section{Introduction}

Methicillin-resistant Staphylococcus aureus (MRSA) and vancomycin-resistant Enterococcus faecalis/faecium (VRE) are among the most problematic pathogens in hospitalacquired infections. Moreover, two clinical isolate strains of vancomycin-resistant $S$. aureus (VRSA) have been isolated from patients in USA since 2002 [1]. Today, only a few drugs such as linezolid [2], quinupristin/dalfopristin [2] and daptomycin [2] are clinically used for both VRE and MRSA infections. Therefore, the development of novel drugs effective for VRE and MRSA (VRSA) is greatly desired.

M. Igarashi, R. Sawa, N. Kinoshita, H. Hashizume, N. Nakagawa, Y. Homma, Y. Nishimura, Y. Akamatsu: Microbial Chemistry Research Center, 3-14-23 Kamiosaki, Shinagawa-ku, Tokyo 141, Japan
In the course of screening for new antimicrobial substances from microorganisms, we found that an actinomycete strain isolated from a soil collected in Tokyo, Japan, produces a new cyclic peptide antibiotic, which was named pargamicin A (1, Fig. 1). Compound 1 showed strong antibacterial activity against MRSA and VRE.

In this paper, we describe the identification of the producing organism, isolation, fermentation, structure elucidation and biological activities of $\mathbf{1}$.

\section{Materials and Methods}

\section{General}

Optical rotation was measured with a Perkin-Elmer model 241 polarimeter. UV spectra were recorded with a Hitachi 557 spectrophotometer. The IR spectrum was recorded with a Horiba FT-210 Fourier transform infrared spectrometer. The ${ }^{1} \mathrm{H}$ - and ${ }^{13} \mathrm{C}$-NMR spectra were measured with a JEOL JNM-A500 spectrometer at $24^{\circ} \mathrm{C}$ using TMS as an internal

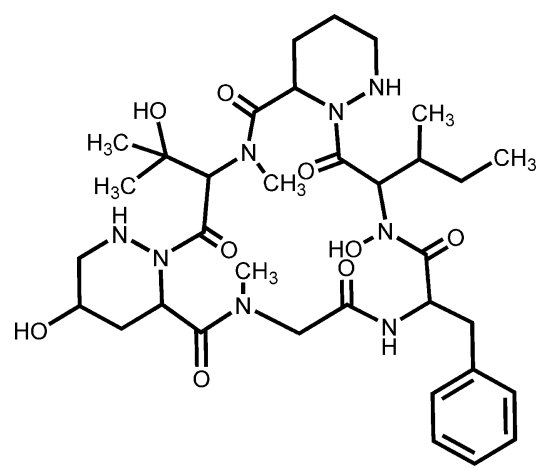

Fig. 1 Structure of pargamicin A (1). 


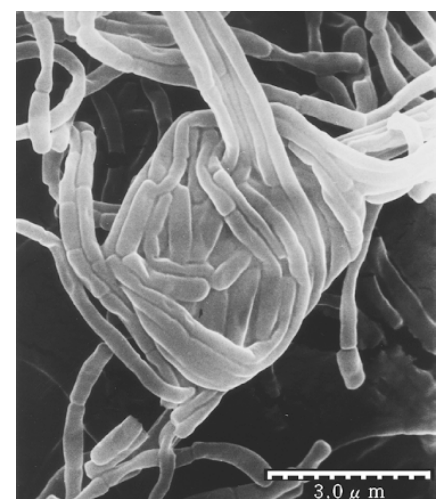

Photo 1 Scanning electron micrograph of strain ML1-hF4 grown on sucrose-nitrate agar for 12 days at $27^{\circ} \mathrm{C}$.

reference. The mass spectrum was recorded with a JEOL JMS-SX102 mass spectrometer.

\section{Taxonomy}

The pargamicin A-producing organism, strain ML1-hF4 was isolated from a soil sample collected at Shinagawa, Tokyo, Japan. Morphological, cultural and physiological properties of the strain ML1-hF4 were examined according to the methods described by SHIRLING and Gottlieb [3], and Waksman [4]. Detailed observation of mycelial morphologies was performed with the use of a scanning electron microscope (Model S-570, Hitachi) after strain ML1-hF4 was incubated on sucrose-nitrate agar at $27^{\circ} \mathrm{C}$ for 12 days. Chemical analysis of the cell wall was performed using TLC according to the method of Staneck and Roberts [5]. Whole-cell sugars were determined by the methods of Lechevalier and Lechevalier [6]. Menaquinones were extracted following the method of Collins et al. [7], and analyzed by LC-MS (model M-1200H, Hitachi) with a CAPCELL PAK AG, $\mathrm{C}_{18}$ column $(4.6 \mathrm{~mm} \times 150 \mathrm{~mm}$, Shiseido Co., Ltd., Japan) using $\mathrm{MeOH}$ - isopropanol (2:1, $\mathrm{v} / \mathrm{v})$ as the mobile phase. Phospholipids and mycolic acids were analyzed by the procedures of Minnikin et al. [8, 9]. A total DNA sample of strain ML1-hF4 was prepared as reported [10]. The $16 \mathrm{~S}$ ribosomal RNA gene (16S rDNA) was amplified by polymerase chain reaction (PCR) using genomic DNA of strain ML1-hF4 and sequenced [11]. A homology search for the most related sequences was performed using the BLAST algorithm on the DDBJ/Genebank/EMBL.

\section{Fermentation}

A slant culture of the pargamicin-producing organism was inoculated into a 500-ml baffled Erlenmeyer flask containing $110 \mathrm{ml}$ of a seed medium consisting of glycerol
$1.0 \%$, dextrin $1.0 \%$, Soytone Peptone (Difco) $0.5 \%$, yeast extract $1.5 \%,\left(\mathrm{NH}_{4}\right)_{2} \mathrm{SO}_{4} \quad 1.0 \%$ and $\mathrm{CaCO}_{3} \quad 1.0 \%$ in deionized water ( $\mathrm{pH} 7.4$ before sterilization). The culture was incubated on a rotary shaker $(180 \mathrm{rpm})$ at $30^{\circ} \mathrm{C}$ for 3 days. A $2.5 \mathrm{ml}$ aliquot of the seed culture were transferred into a 500-ml Sakaguchi flask containing $125 \mathrm{ml}$ of a producing medium consisting of galactose $2.0 \%$, dextrin $2.0 \%$, glycerol $1.0 \%$, Soytone Peptone (Difco) $0.5 \%$, corn steep liquor $0.5 \%$ and $\mathrm{CaCO}_{3} 0.2 \%$ in deionized water. The fermentation was carried out on a reciprocal shaker (130 rpm) at $27^{\circ} \mathrm{C}$ for 5 days.

\section{Analytical Procedure}

The content of $\mathbf{1}$ in the fermentation broth and the various purification steps was monitored with reversed-phase HPLC and silica gel TLC. HPLC was performed with a CAPCELL PAK, AG, $\mathrm{C}_{18}$ column $(4.6 \times 150 \mathrm{~mm}$, Shiseido Co., Ltd., Japan; mobile phase, $\mathrm{CH}_{3} \mathrm{CN}: \mathrm{H}_{2} \mathrm{O}=35$ : 65; flow rate, $2.0 \mathrm{ml} /$ minute; column temperature, $50^{\circ} \mathrm{C}$; detection, $\mathrm{UV}$ at $238 \mathrm{~nm}$ ). Compound $\mathbf{1}$ was eluted at 7.5 minutes. The antibiotic was detected on TLC plates with a solution of mixture of molybdophosphoric acid and sulfuric acid in $\mathrm{MeOH}$ and UV light $(254 \mathrm{~nm})$. Pargamicin A showed TLC (Kieselgel $60 \mathrm{~F}_{254}$, Art. No. 1.05715, Merck) Rf values of 0.82 and 0.44 with solvent system of $\mathrm{CHCl}_{3}: \mathrm{MeOH}=19: 1$ and $\mathrm{EtOAc}: \mathrm{MeOH}=4: 1$, respectively.

\section{Biological Activity}

The MIC of pargamicin A were examined by serial agar dilution method using Mueller-Hinton agar (Difco) for bacteria including Enterococci and Staphylococcus aureus [12]. The MIC was observed against bacteria and yeast after incubation for 18 hours at $37^{\circ} \mathrm{C}$.

\section{Results and Discussion}

\section{Taxonomic Features of Strain ML1-hF4}

Strain ML1-hF4 produced well-branched substrate mycelia. Aerial hyphae were straight or flexuous. Both substrate and aerial hyphae exhibited nocardioform fragmentation. The spore was cylindrical with a smooth surface and $0.4 \sim 0.6 \times 0.8 \sim 1.6 \mu \mathrm{m}$ in size (Fig. 1). No synnemata, sclerotia, sporangia or motile spores were observed.

The taxonomic properties of strain ML1-hF4 are shown in Table 1. Whole-cell hydrolysates of strain ML1-hF4 contained meso-diaminopimelic acid of the cell wall and galactose and arabinose. The predominant menaquinone was MK-9 $\left(\mathrm{H}_{4}\right)$. The phospholipid pattern was type PII: phosphatidylethanolamine was present, but neither phosphatidylcholine nor unknown glucosamine-containing 
Table 1 Taxonomic characteristics of strain ML1-hF4

\begin{tabular}{|c|c|}
\hline Characteristics & Strain ML1-hF4 \\
\hline Amino acid of cell wall & meso-diaminopimelic acid \\
\hline Whole cell sugar pattern & A (arabinose, galactose) \\
\hline Major menaquinones & MK-9 $\left(\mathrm{H}_{4}\right)$ \\
\hline Phospholipid composition & PII \\
\hline Mycolic acids & None \\
\hline Fragmentation of hyphae & Positive \\
\hline Color of aerial mycelium & White \\
\hline Color of substrate mycelium & Pale yellow pale brown \\
\hline Soluble pigment & None \\
\hline
\end{tabular}

phospholipids were found. Mycolic acids were absent. The aerial mycelia of strain ML1-hF4 were white on various agar media. The substrate mycelia were pale yellow to pale brown. Soluble pigments were not produced. Permissive temperature ranges for growth of the strain were $20 \sim 37^{\circ} \mathrm{C}$. The optimal temperature for growth of the strain ML1-hF4 was $30^{\circ} \mathrm{C}$.

The partial 16S rDNA sequence $(457 \mathrm{bp}$, positions 27 510, Escherichia coli numbering system [13]) of strain ML1-hF4 showed high similarity value with members of the genus Amycolatopsis, such as Amycolatopsis albidoflavus AB327251 (444/457, 97\%), A. halotorelans DQ000196 (443/458, 96\%), A. echigoensis AB248535 (443/459, 96\%) and A. niigatensis AB248537 (441/458, $96 \%)$.

These phenotypic and genotypic properties suggested that strain ML1-hF4 belonged to the genus Amycolatopsis [14].

Therefore, the strain was identified as an Amycolatopsis sp. and designated Amycolatopsis sp. ML1-hF4. Detailed taxonomic study of strain ML1-hF4 is in progress.

\section{Fermentation and Isolation}

The fermentation broth (5.0 liters) was separated to the mycelial cake and supernatant by centrifugation. The supernatant was applied on a Diaion HP20 (Mitsubishi Chemical Co.) column $(38 \times 155 \mathrm{~mm})$. The column was washed with deionized water $(450 \mathrm{ml})$ and $50 \%$ aq $\mathrm{MeOH}$ $(450 \mathrm{ml})$. The active principle was eluted with $80 \%$ aq $\mathrm{MeOH}(450 \mathrm{ml})$ and $80 \%$ aq $\mathrm{Me}_{2} \mathrm{CO}(450 \mathrm{ml})$. The active solutions were collected and concentrated in vacuo to yield a brown oil $(576 \mathrm{mg})$. The brown oil containing the active substance was chromatographed on a silica gel column with stepwise development comprising successive $300 \mathrm{ml}$ aliquots of EtOAc: $\mathrm{MeOH}$ mixtures of compositions $10: 1$, $9: 1,4: 1$ and $2: 1$, respectively. The active fractions were

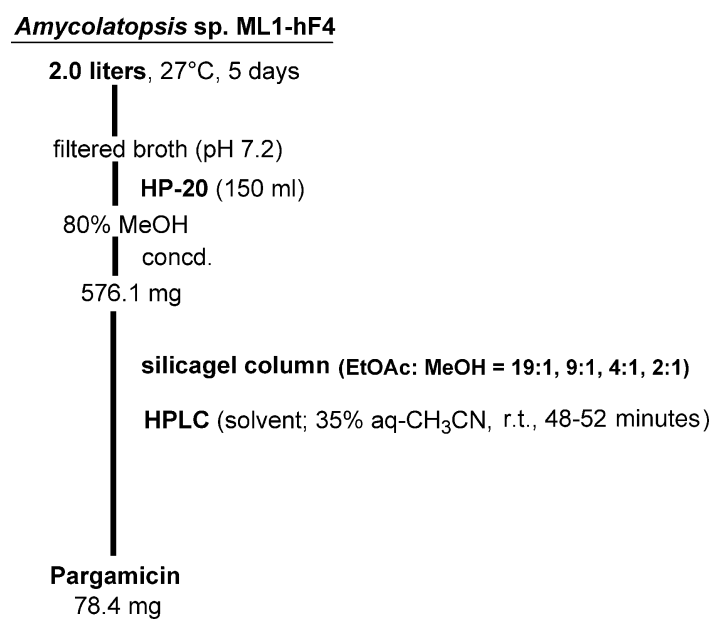

Fig. 2 Isolation procedure of pargamicin A (1).

Table 2 Physico-chemical properties of pargamicin A (1)

\begin{tabular}{|c|c|}
\hline Molecular formula & $\mathrm{C}_{34} \mathrm{H}_{52} \mathrm{~N}_{8} \mathrm{O}_{9}$ \\
\hline \multirow[t]{2}{*}{ FAB-MS $(m / z)$} & $717(\mathrm{M}+\mathrm{H})^{+}$ \\
\hline & $715(\mathrm{M}-\mathrm{H})^{-}$ \\
\hline HRFAB-MS Calcd: & 717.3936 (as $\mathrm{C}_{34} \mathrm{H}_{53} \mathrm{~N}_{8} \mathrm{O}_{9}$ ) \\
\hline Found: & $717.3917(\mathrm{M}+\mathrm{H})^{+}$ \\
\hline$[\alpha]_{D}^{25}$ & $+11.3^{\circ}$ (c 0.927, $\left.\mathrm{MeOH}\right)$ \\
\hline$\cup V \lambda_{\max }^{\mathrm{MeOH} n m(\varepsilon)}$ & end \\
\hline $\mathrm{IR} v_{\max }(\mathrm{KBr}) \mathrm{cm}^{-1}$ & $\begin{array}{l}3600 \sim 3200,2968,2933,1624 \\
1545,1493,1464,1406,1275,1255 \\
1190,1153,1128,1092,964,920\end{array}$ \\
\hline Color reaction & $\mathrm{I}_{2}$, molybdophosphoric acid-sulfuric acid \\
\hline positive & $\mathrm{FeCl}_{3}$, Rydon-Smith \\
\hline
\end{tabular}

collected and concentrated in vacuo to give a pale brown powder $(158 \mathrm{mg})$. The active material was further purified by reversed phase HPLC developing with $\mathrm{CH}_{3} \mathrm{CN}$ : $\mathrm{H}_{2} \mathrm{O}=35: 65$ (CAPCELL PAK C18 UG120, 4.6×150 mm, Shiseido Co., Ltd. Japan, flow rate, $8.0 \mathrm{ml} /$ minute). The active fractions were collected and concentrated in vacuo to give 1 ( $78 \mathrm{mg}$, Fig. 2) as colorless powder.

\section{Structure Elucidation of Pargamicin}

The physico-chemical properties of pargamicin are summarized in Table 2. The molecular formula of pargamicin was determined to be $\mathrm{C}_{34} \mathrm{H}_{52} \mathrm{~N}_{8} \mathrm{O}_{9}$ by HRFABMS. Its characteristic IR absorbances at 1624 and $1545 \mathrm{~cm}^{-1}$ and the positive color reaction with RydonSmith reagent revealed the presence of amide moiety, and the positive reaction in the $\mathrm{FeCl}_{3}$ color test also indicated the presence of an $\mathrm{N}$-hydroxy moiety. The relationships between specific proton and carbon signals in the ${ }^{1} \mathrm{H}$ - and 


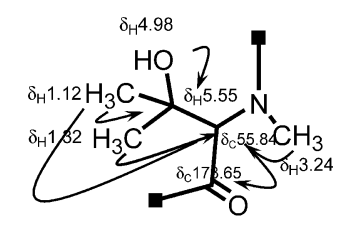

N-Me-3-OH-Val

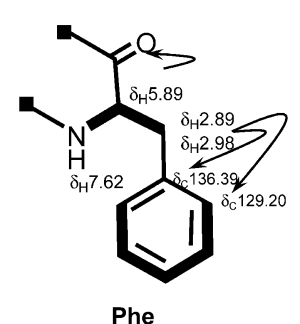

Phe

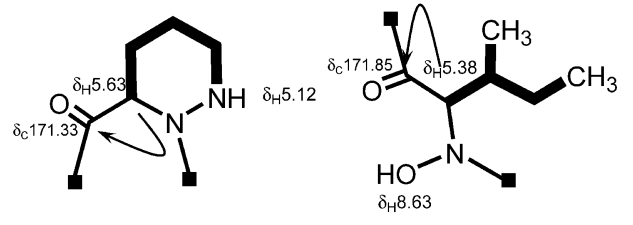

Pip

$\mathrm{N}-\mathrm{OH}-\mathrm{Ile}$

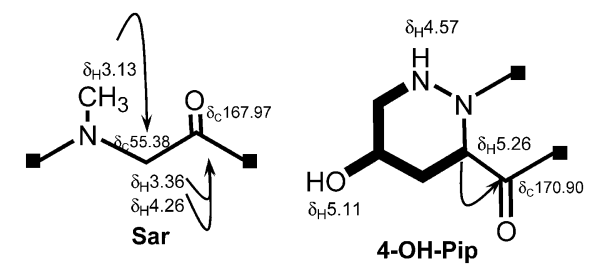

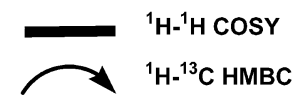

Fig. 3 Partial structures of pargamicin A (1).

${ }^{13} \mathrm{C}$-NMR data of pargamicin were established by DEPT and HMQC spectra. These spectra revealed the presence of six carbonyls, six $s p^{2}$ phenyl, twelve $s p^{3}$ methines, eight methylenes and six methyl groups. Analyses of ${ }^{1} \mathrm{H}-{ }^{1} \mathrm{H}$ COSY and HMBC spectra revealed six partial structures, as shown in Fig. 3. The ${ }^{1} \mathrm{H}$ connection from $\mathrm{NH}\left(\delta_{\mathrm{H}} 7.62\right)$ to methylene protons ( $\delta_{\mathrm{H}} 2.89$ and 2.98) and long range correlation from these methylene protons to phenyl carbons at $\delta_{\mathrm{C}} 136.29$ and 129.20 , together with that of an $\alpha$ methine $\left(\delta_{\mathrm{H}} 5.89\right)$ to $\delta_{\mathrm{C}} 172.74$ showed the presence of a phenylalanine (Phe) moiety. The long range HMBC couplings between an $N$-methyl $\left(\delta_{\mathrm{H}} 2.89\right)$ and a methylene at $\delta_{\mathrm{C}} 55.38$ and the methylene protons $\left(\delta_{\mathrm{H}} 3.36,4.26\right)$ and $\delta_{\mathrm{C}} 167.97$ revealed the presence of $N$-methylglycine (sarcosine: Sar). The ${ }^{1} \mathrm{H}^{-}{ }^{1} \mathrm{H}$ spin network from an $\alpha$ methine $\left(\delta_{\mathrm{H}} 5.26\right)$ to $\mathrm{NH}\left(\delta_{\mathrm{H}} 4.57\right)$ as well as hydroxyl proton $\left(\delta_{\mathrm{H}} 5.11\right)$ and the long range coupling between the $\alpha$-methine and $\delta_{\mathrm{C}} 170.90$ suggested the presence of 4 hydroxypiperazic acid (4-OH-Pip) residue. The long range correlations from dimethyl protons $\left(\delta_{\mathrm{H}} 1.12,1.32\right)$ and hydroxyl proton $\left(\delta_{\mathrm{H}} 4.98\right)$ to a quartanary carbon $\left(\delta_{\mathrm{C}}\right.$ 73.42) and $\alpha$-methine $\left(\delta_{\mathrm{C}} 55.84\right)$, together with those from the methine $\left(\delta_{\mathrm{H}} 5.55\right)$ to $\delta_{\mathrm{C}} 173.65$ and from $N$-methyl group $\left(\delta_{\mathrm{H}} 3.24\right)$ to the methine indicated the presence of an $\mathrm{N}$-methyl-3-hydroxyvaline ( $N$-Me-3-OH-Val) residue. The proximity of an $\alpha$-methine $\left(\delta_{\mathrm{H}} 5.63\right)$ to an $\mathrm{NH}$ proton $\left(\delta_{\mathrm{H}}\right.$ 5.12) and the long range correlations between $\alpha$-methine and $\delta_{\mathrm{C}} 171.33$ showed the presence of a piperazic acid residue (Pip). Lastly, COSY correlation indicated a connection between branched methyl protons $\left(\delta_{\mathrm{H}} 1.33 \mathrm{t}\right.$, $0.80 \mathrm{~d})$ to an $\alpha$-methine $\left(\delta_{\mathrm{H}} 5.38, \mathrm{~d}\right)$ while a long range HMBC correlation from the same $\alpha$-methine to a carbonyl

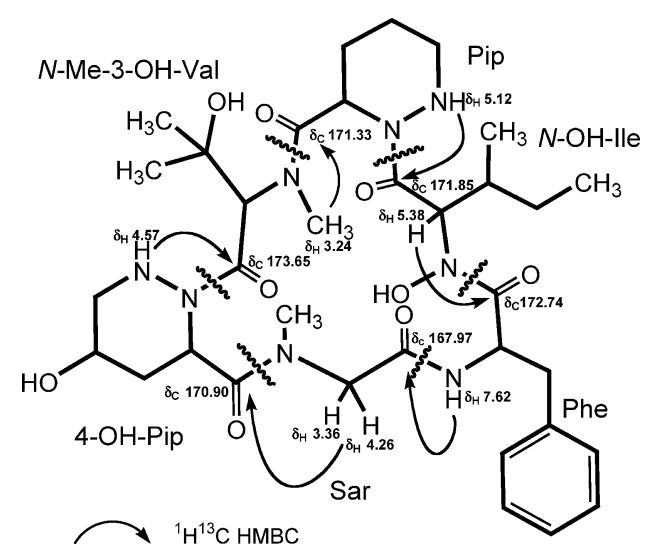

Fig. 4 Selected HMBC correlations of pargamicin A (1).

at $\delta_{\mathrm{C}} 167.97$, revealed the presence of an $N$-substituted isoleucine moiety. The remaining exchangeable proton $\left(\delta_{\mathrm{H}}\right.$ $8.63, \mathrm{~s})$ did not show any correlations in a ${ }^{1} \mathrm{H}-{ }^{15} \mathrm{~N}$ HMQC experiment, suggesting the presence of an $N$-hydroxyl group. This amino acid residue was therefore postulated to be $N$-hydroxy-isoleucine ( $N$-OH-Ile).

The connectivity between these residues was established by the key $\mathrm{HMBC}$ correlations illustrated in Fig. 4 as follows; $\mathrm{NH}$ proton $\left(\delta_{\mathrm{H}} 7.62\right)$ of Phe to $\mathrm{C}=\mathrm{O}$ carbon $\left(\delta_{\mathrm{C}}\right.$ 167.97) of Sar, methylene protons $\left(\delta_{\mathrm{H}} 3.36,4.26\right)$ of Sar to $\mathrm{C}=\mathrm{O}$ carbon $\left(\delta_{\mathrm{C}} 170.90\right)$ of $4-\mathrm{OH}-\mathrm{Pip}, \mathrm{NH}$ proton $\left(\delta_{\mathrm{H}}\right.$ 4.57) of 4-OH-Pip to $\mathrm{C}=\mathrm{O}$ carbon $\left(\delta_{\mathrm{C}} 173.65\right)$ of $N$-Me-3$\mathrm{OH}-\mathrm{Val}, N$-Me protons $\left(\delta_{\mathrm{H}} 3.24\right)$ of $N$-Me-3-OH-Val to $\mathrm{C}=\mathrm{O}$ carbon $\left(\delta_{\mathrm{C}} 171.33\right)$ of Pip, NH proton $\left(\delta_{\mathrm{H}} 5.12\right)$ of Pip to $\mathrm{C}=\mathrm{O}\left(\delta_{\mathrm{C}} 171.85\right)$ of $N$-OH-Ile and $\alpha$-methine proton $\left(\delta_{\mathrm{H}} 5.38\right)$ of $N$-OH-Ile to $\mathrm{C}=\mathrm{O}$ carbon $\left(\delta_{\mathrm{C}} 172.74\right)$ of Phe, by HMBC spectrum. These results revealed that 
Table $3{ }^{1} \mathrm{H}$ - and ${ }^{13} \mathrm{C}-\mathrm{NMR}$ data for Pargamicin $\mathrm{A}(\mathbf{1})$ in $\mathrm{CDCl}_{3}$

\begin{tabular}{|c|c|c|c|c|c|c|c|c|c|}
\hline Position & $\delta_{\mathrm{C}}$ & $\delta_{\mathrm{H}}$ & $J(H z)$ & & Position & $\delta_{\mathrm{C}}$ & $\delta_{\mathrm{H}}$ & & $J(H z)$ \\
\hline \multirow[t]{9}{*}{ 4OHPip } & $\alpha$ & $48.06 \mathrm{~d}$ & $5.26 \mathrm{~d}$ & 6.2 & NOHIle & $\alpha$ & $60.97 d$ & $5.38 d$ & 6.0 \\
\hline & $\beta$ & $31.40 \mathrm{t}$ & $2.11 \mathrm{~m}$ & & & $\beta$ & $34.91 \mathrm{~d}$ & $2.11 \mathrm{~m}$ & \\
\hline & & & $2.51 \mathrm{~d}$ & 14.3 & & $\beta$-Me & $15.33 q$ & $0.59 \mathrm{t}$ & 6.9 \\
\hline & $\gamma$ & $61.89 d$ & 3.93 m & & & $\gamma$ & $25.43 t$ & $1.33 \mathrm{~m}$ & \\
\hline & $\gamma-\mathrm{OH}$ & & $5.11 \mathrm{brs}$ & & & $\delta$ & $12.92 \mathrm{q}$ & $0.80 d$ & 7.4 \\
\hline & $\delta$ & $52.85 \mathrm{t}$ & $2.95 \mathrm{~m}$ & & & $\mathrm{CO}$ & $171.85 \mathrm{~s}$ & & \\
\hline & & & $3.04 \mathrm{~m}$ & & & $\mathrm{NOH}$ & & $8.63 \mathrm{~s}$ & \\
\hline & $\mathrm{CO}$ & $170.90 \mathrm{~s}$ & & & & & & & \\
\hline & $\mathrm{NH}$ & & $4.57 \mathrm{dd}$ & $2.5,13.0$ & Phe & $\alpha$ & $47.71 \mathrm{~d}$ & 5.89 ddd & $6.0,10.4,10.4$ \\
\hline \multirow[t]{7}{*}{$\mathrm{NMe}_{3} \mathrm{OHVal}$} & $\alpha$ & $55.84 d$ & $5.55 \mathrm{~s}$ & & & $\beta$ & $37.61 \mathrm{t}$ & $2.89 \mathrm{dd}$ & $6.0,13.3$ \\
\hline & $\beta$ & $73.42 \mathrm{~s}$ & & & & & & $2.98 \mathrm{~m}$ & $10.4,13.3$ \\
\hline & $\beta-\mathrm{OH}$ & & $4.98 \mathrm{~s}$ & & & 1 & $136.39 \mathrm{~s}$ & & \\
\hline & $\gamma$ & $25.54 \mathrm{q}$ & $1.12 \mathrm{~s}$ & & & $2 / 6$ & $129.20 \mathrm{~d}$ & $7.22 \mathrm{~m}$ & \\
\hline & $\gamma$ & $28.71 \mathrm{q}$ & $1.32 \mathrm{~s}$ & & & $3 / 5$ & $128.37 d$ & $7.22 \mathrm{~m}$ & \\
\hline & $\mathrm{CO}$ & $173.65 \mathrm{~s}$ & & & & 4 & $126.65 d$ & 7.17 m & \\
\hline & NMe & $33.62 \mathrm{q}$ & $3.24 \mathrm{~s}$ & & & $\mathrm{CO}$ & $172.74 \mathrm{~s}$ & & \\
\hline \multirow[t]{7}{*}{ Pip } & $\alpha$ & $43.00 d$ & $5.63 \mathrm{dd}$ & $2.0,5.2$ & & $\mathrm{NH}$ & & $7.62 \mathrm{~d}$ & 10.4 \\
\hline & $\beta$ & $25.04 \mathrm{t}$ & $1.85 \mathrm{~m}$ & & Sar & $\alpha$ & $55.38 \mathrm{t}$ & $3.36 \mathrm{~d}$ & 16.3 \\
\hline & $\gamma$ & $18.84 t$ & $1.47 \mathrm{brd}$ & 13.0 & & & & $4.26 \mathrm{~d}$ & 16.3 \\
\hline & & & $2.38 \mathrm{~m}$ & & & $\mathrm{CO}$ & $167.97 \mathrm{~s}$ & & \\
\hline & $\delta$ & $48.06 \mathrm{t}$ & $\begin{array}{l}2.67 \mathrm{ddd} \\
3.11 \mathrm{~m}\end{array}$ & $3.1,13.0,13.0$ & & NMe & $38.07 \mathrm{q}$ & $3.13 \mathrm{~s}$ & \\
\hline & $\mathrm{CO}$ & $171.33 \mathrm{~s}$ & & & & & & & \\
\hline & $\mathrm{NH}$ & & $5.12 \mathrm{~m}$ & & & & & & \\
\hline
\end{tabular}

Chemical shifts are given in ppm adjusted with TMS as internal standard.

pargamicin is a new cyclic hexapeptide consisting of cyclo(Phe-Sar-(4-OH-Pip)-(N-Me-3-OH-Val)-Pip-( $N$-OHIle)).

Pargamicin has a unique cyclic peptide containing $N$-methyl- and $N$ or $C$-hydroxyl-amino acids. The stereochemistry and the structures of other analogs of pargamicin will be reported later.

\section{Biological Activity}

The antimicrobial activities of $\mathbf{1}$ are shown in Table 4 . Pargamicin A (1) showed strong antimicrobial activities against Gram-positive bacteria including MRSA and VRE strains (Table 3). Its MICs were $0.39 \sim 0.78 \mu \mathrm{g} / \mathrm{ml}$ for susceptible $S$. aureus and multidrug-resistant $S$. aureus including MRSA, and $0.39 \mu \mathrm{g} / \mathrm{ml}$ for susceptible $E$. faecalis/faecium $(n=2)$ and vancomycin resistant $E$. faecalis/faecium $(n=4)$. However, 1 showed no activity at $100 \mu \mathrm{g} / \mathrm{ml}$ against pathogenic Gram-negative bacteria and yeast such as Salmonella enteritidis and Candida albicans, respectively.

\section{Discussion}

Our screening program for new antibiotics has yielded a new anti-MRSA and anti-VRE agent designated pargamicin A (1) from an Amycolatopsis sp. Compound 1 showed strong antimicrobial activities against MRSA and VRE. It is worth noting that $\mathbf{1}$ showed more potent activity against VRE than current anti-VRE drugs. Structural studies revealed that $\mathbf{1}$ is a cyclic hexapeptide antibiotic containing unusual residues including piperazic acid and $\mathrm{N}$ methyl and $N$ - or $C$-hydroxyl amino acid. Compound $\mathbf{1}$ is a cyclic peptide antibiotic containing piperazic acid. This residue is an unusual amino acid that has been found previously in peptides or cyclic depsipeptides from actinomycetes but has previously only been described once as a component of an actinomycete-derived cyclic peptide. L 156373, discovered as oxtocin and vasopressin antagonist in 1989 by Pettibone D. J. et al. is the sole example from a Streptomyces [15]. While L 156373 shares structural similarities with 1, it has no anti-MRSA/VRE activities. These results indicate that $\mathbf{1}$ should be an interesting lead compound for the development of novel anti-MRSA/VRE 
Table 4 Antibacterial activities of pargamicin A (1)

\begin{tabular}{|c|c|c|c|}
\hline \multirow[b]{2}{*}{ Test organisms } & \multirow[b]{2}{*}{ Strain } & \multicolumn{2}{|c|}{$\mathrm{MIC}(\mu \mathrm{g} / \mathrm{ml})$} \\
\hline & & Pargamicin A & Vancomycin \\
\hline Enterococcus faecalis & JCM 5803 & 0.39 & 0.78 \\
\hline E. faecalis & NCTC 12201 (VRE, vanA) & 0.39 & $>400$ \\
\hline E. faecalis & NCTC 12203 (VRE, vanA) & 0.39 & $>400$ \\
\hline E. faecium & JCM 5804 & 0.39 & 0.78 \\
\hline E. faecium & NCTC 12202 (VRE, vanA) & 0.39 & $>400$ \\
\hline E. faecium & NTCTC 12204 (VRE, vanA) & 0.39 & $>400$ \\
\hline Staphylococcus aureus & FDA 209P & 0.78 & 0.39 \\
\hline S. aureus & Smith & 0.78 & 0.39 \\
\hline S. aureus & MS 9610 (MDR) & 0.78 & 0.78 \\
\hline S. aureus & MS 16526 (MRSA) & 0.78 & 0.78 \\
\hline S. aureus & TY-04282 (MRSA) & 0.78 & 0.78 \\
\hline Escherichia coli & $\mathrm{NIHJ}$ & $>100$ & $>100$ \\
\hline Shigella dysenteriae & JS 11910 & $>100$ & $>100$ \\
\hline Salmonella enteritidis & & $>100$ & $>100$ \\
\hline Pseudomonas aeruginosa & A3 & $>100$ & $>100$ \\
\hline Klebsiella pneumonie & PCI 602 & $>100$ & $>100$ \\
\hline Candida albicans & 3147 & $>100$ & $>100$ \\
\hline
\end{tabular}

Muller Hinton agar, $37^{\circ} \mathrm{C}, 18$ hours. VRE: vancomycin resistant Enterococcus. MDR: multidrug resistant, MRSA: Methicillin resistant Staphylococcus aureus.

drugs based on the new mode of action. Studies on the mode of action of $\mathbf{1}$ and the structure-activity relations are under investigation.

Acknowledgements We thank Mrs. Seiko Hattori for measuring the MIC and Mrs. Yumiko Kubota for measuring the NMR spectra.

\section{References}

1. Tenover FC, Weigel LM, Appelbaum PC, McDougal LK, Chaitram J, McAllister S, Clark N, Killgore G, O'Hara CM, Jevitt L, Patel JB, Bozdogan B. Vancomycin-resistant Staphylococcus aureus isolate from a patient in Pennsylvania. Antimicrob Agents Chemother 48: 275-280 (2004)

2. Rybak MJ, Hershberger E, Moldovan T, Grucz RG. In vitro activities of daptomycin, vancomycin, linezolid, and quinupristin-dalfopristin against Staphylococci and Enterococci, including vancomycin-intermediate and -resistant strains. Antimicrob Agents Chemother 44: 1062-1066 (2000)

3. Shiring EB, Gottlieb D. Methods for characterization of Streptomyces species. Int J Syst Bacteriol 16: 313-340 (1966)
4. Waksman SA. Classification, identification and descriptions of genera and species. In the Actinomycetes, Vol. II, pp. 327-334, The Williams \& Wilkins Co., Baltimore (1961)

5. Staneck JL, Roberts GD. Simplified approach to identification of aerobic actinomycetes by thin-layer chromatography. Appl Microbiol 28: 226-231 (1974)

6. Lechevalier MP, Lechevalier HA. The chemotaxonomy of actinomycetes. In Actinomycete taxonomy Ed., Dietz $\mathrm{AD}$ et al., pp. 227-291, Society for Industrial Microbiology, Virginia (1980)

7. Collins MD, Pirouz T, Goodfellow M, Minnikin DE. Distribution of menaquinones in actinomycetes and corynebacteria. J Gen Microbiol 100: 221-230 (1977)

8. Minnikin DE, Patel PV, Alshamaony L, Goodfellow M. Polar lipid composition in the classification of Nocardia and related bacteria. Int J Syst Bacteriol 27: 104-117 (1977)

9. Minnikin DE, Hutchinson IG, Caldicott AB, Goodfellow M. Thin-layer chromatography of methanolysates of mycolic acid-containing bacteria. J Chromatography 188: 221-233 (1980)

10. Hamada M, Kinoshita N, Hattori S, Yoshida A, Okami Y, Higashide K, Sakata N, Hori M. Streptomyces kasugaensis sp. nov.: A new species of genus Streptomyces. Actinomycetol 9: 27-36 (1995)

11. Kinoshita N, Igarashi M, Ikeno S, Hori M, Hamada M. Saccharothrix tangerinus sp. nov., the producer of the new antibiotic formamicin: taxonomic studies. Actinomycetol 
13: 20-31 (1999)

12. Japan Society of Chemotherapy. Method of MIC determination. Chemother 29: 77-79 (1981) (in Japanese)

13. Brosius J, Palmer ML, Kennedy PJ, Noller HF. Complete nucleotide sequence of a 16S ribosomal RNA gene from Escherichia coli. Proc Natl Acad Sci USA 75: 4801-4805 (1978)

14. Lechevalier MP, Prauser H, Labeda DP, Ruan JS. Two new genera of Nocardioform Actinomycetes: Amycolata gen. nov. and Amycolatopsis gen. nov. Int J Syst Bacteriol 36: 29-37 (1986)

15. Pettibone DJ, Clineschmidt BV, Anderson PS, Freidinger RM, Lundell GF, Koupal LR, Schwartz CD, Williamson JM, Goetz MA, Hensens OD, et al. A structurally unique, potent, and selective oxytocin antagonist derived from Streptomyces silvensis. Endocrinology 125: 217-222 (1989) 